\title{
Law Reform and the Legal Services Crisis
}

\author{
Lawrence A. Sullivan*
}

II ANY OF THE local legal service programs ${ }^{1}$ supported by $\mathrm{OEO}^{2}$ have sought to aid poor clients through strategies ${ }^{3}$ whicl, broadly speaking, are aimed at either of two interrelated goals: first, increasing the resources society allocates to the needs of the poor either as the direct consequence of litigation or by generating, through litigation and other devices, the kinds of tensions around unmet needs that may stimulate pohtical processes to allocate greater resources to their fulfillment; second, stimulating the creation among the poor of new organizations through which they may be able to work collectively, either through political or economic means, or both, toward the alleviation of their economic and social problems. ${ }^{4}$ Notably, legal service lawyers have in the past few years prosecuted and won literally dozens of cases which have made new law of potentially great significance to the poor in welfare, ${ }^{6}$ housing, ${ }^{6}$ and other areas. ${ }^{7}$

* Professor of Law, University of California, Berkeley. A.B. 1948, U.C.L.A.; LL.B. 1951, Harvard University. Professor Sullivan is a menber of the governing board of the National Housing and Economic Development Law Project and recently undertook an internal review of its objectives and operations at the Project's request. While this Article draws upon research performed in connection with that review, sone of which was financed by a grant from the Office of Economic Opportunity, the opinions expressed herein are those of the author and should not be construed as representing the opinions or policy of any agency of the United States Government.

1. Initially, legal services programs were funded under the community action provision of title II-A of the Economic Opportunity Act of 1964, $\$$ 201-11, 78 Stat. 516-20. Today, legal services are specifically provided for. 42 U.S.C. $\$ 2809$ (a)(3) (Supp. V, 1970).

2. See generally Bamberger, The Legal Services Program of OEO, 41 NoTRE DAME LAW. 847 (1966).

3. Strategic planning typifies the "new" legal services approach. See text following note 55 infra.

4. See also P. WALD, LAW AND PoverTY: 1965, at 4-5 (1965).

5. E.g., Shapiro v. Thonipson, 394 U.S. 618 (1969) (statutory provisions denying welfare on the basis of residency requirements held violative of equal protection clause); King v. Smith, 392 U.S. 309 (1968) (state "substitute father" regulation denying aid to dependent children, otherwise eligible, on ground that nother cohabits with an able bodied nuan held inconsistent with federal law and policy); Anderson v. Burson, 300 F. Supp. 401 (N.D. Ga. 1968) (state "eniployable mother" rule held to violate equal protection clause).

6. E.g., Javins v. First Nat'l Realty Corp., 428 F.2d 1071 (D.C. Cir.), cert. 
Lawyering of the kind that is aimed at making new law of significance for the poor is not the only element and, at least as yet, may not be the dominant element in the OEO legal service program. During the mid-1960's, when the legal services program was taking shape, there was a lively professional literature in which goals of the program and the ways in which they should be sought were debated with some vigor. ${ }^{8}$ The program has now been functioning for half a decade. It has evolved in operation a form, character, and orientation that differ in significant respects from anything that contributors to the initial debate had envisaged. Yet debate continues. Now that some of the program's more important impacts are beginning to be felt, debate has moved from the law reviews to political media and the pages of the daily paper. ${ }^{0}$

The goal of the legal service program has been to provide quality legal services to the poor with the expectation that such services may be

denied, 400 U.S. 925 (1970) (residential tenancy includes a nonwaivable warranty of habitability); Edwards v. Habib, 397 F.2d 687 (D.C. Cir.), cert. denied, 393 U.S. 1016 (1968) (retaliatory eviction upon filing of housing code complaint held illegal); Brown v. Southall Realty Co., 237 A.2d 834 (D.C. Ct. App. 1968) (defense of illegal contract available upon landlord's suit for possession for nonpayment of rent where serious building code violations existed at time of letting); North City Area Wide Counsel, Inc. v. Romney, 428 F.2d 754 (3d Cir. 1970) (citizen's groups given standing to challenge decisions under Model Cities program for lack of adequate citizen participation); Tenants \& Owners in Opposition to Redevelopment v. HUD, Civil No. 69324 (N.D. Cal., Apr. 30, 1970) (federally aided redevelopment projects enjoined because of deficiencies in relocation plan); Western Addition Community Org. v. Weaver, 294 F. Supp. 433 (N.D. Cal. 1968) (same); Escalera v. New York City Housing Auth., 425 F.2d 853 (2d Cir.), cert. denied, 400 U.S. 853 (1970) (procedural and substantive due process requirements applicable to city's administration of public housing project).

7. E.g., Harris v. Harris, 428 F.2d 806 (D.C. Cir. 1970) (suit for divorce may be brought in forma pauperis); Perry v. Grenada Muricipal School Dist., 300 F. Supp. 748 (N.D. Miss. 1969) (blanket exclusion of unwed mothers from school violates equal protection).

8. E.g., Cahn \& Cahn, The War on Poverty: A Civilian Perspective, 73 YALB L.J. 1317 (1964); Carlin \& Howard, Legal Representation and Class Justice, 12 U.C.L.A.L. Rev. 417 (1965); Frankel, Experiments in Serving the Indigent, 51 A.B.A.J. 460 (1965); Pye, The Role of Legal Services in the Antipoverty Program, 31 LAW \& CONTEMP. PROB. 211 (1966).

9. Recent debate within the administration and between administration officials and members of Congress as to the direction, character, organization, and control of the legal services program has received wide inedia coverage. See, e.g., N.Y. Times, Oct. 8, 1970, at 33, col. 1; N.Y. Times, Nov. 16, 1970, at 12, col. 1. Governor Reagan's veto of the grant to the California Rural Legal Assistance Foundation has produced dramatic headlines. See, e.g., S.F. Examiner, Dec. 27, 1970, at 1, col. 3; S.F. Chronicle, Dec. 28, 1970, at 4, col. 1. See also SubComm. on EMPLoyment, MaNpower, and Poverty of the Senate Comm. on Labor and Public Welfare, 91st Cong., 2D Sess., Legal Services Program Under the OfFice of Economic Opportunity, Selected Replies to Subcommitee Questionaire (Comm. Print 1970) thereinafter cited as SUbCOMMTTIEE QUESTIONAIRE]. 
used to improve the quality of life for poor Americans. ${ }^{10}$ Whether this goal will be realized depends in part on the skill of lawyers in the legal services program and on the kinds of strategies they develop and use. Decisions made at the local level, where caseload pressures are felt most sharply, therefore are of great importance. Until very recently, OEO, the funding agency, has attempted in various ways to give the program a degree of coherence and direction nationally. It has sought, through various administrative techniques, to influence major policy decisions made at the local level. As of this moment, the grant program is still under the administrative control of the Office of Legal Services, a division of OEO, under the supervision of lawyers: a Director, a Deputy Director and several Assistant Directors, each with a rather thin layer of bureaucratic support. At least until recently, the lawyers in charge of the program were convinced that an effective program was dependent upon aggressive lawyering at the local level.11 Therefore, the Office of Legal Services has tried to attract into local offices talented young attorneys committed to the goal of effective legal services for the poor. ${ }^{12}$ It also has encouraged local offices to develop and employ the test case and other so-called law reform strategies which, in addition to aiding particular clients, might achieve significant gains for poor people generally. ${ }^{13}$ However, the present administration has favored administrative changes that would reduce the independence and authority of the Office of Legal Services. ${ }^{14}$ Personnel changes at the highest level have also been made recently which may imply a turn away from the past policy. ${ }^{15}$ Each

10. See generally OEO, National Guidelines for Legal Services ProGRAM (1966).

11. The organizational structure of the legal services program and its development are outlined in 1 CCH Poverty L. Rep. If 6050-70 (1968). See also Subcommitree QuestTONAIRE 6-11.

12. Presently there are 350 Reginald Heber Smith Fellows assigned to legal services offices. SUbCOMMTTTEe QUeSTTONAIRE 7.

13. Address by Earl Johnson, Jr., Harvard Conference on Law and Poverty, March 17, 1967; OEO, supra note 10, at 23; OEO Press Release No. 67-51, Mar. 18, 1967. It may be significant that in his last response-as OEO Director to Congressional inquiries about the program, Mr. Rumsfeld did not greatly emphasize reform activities. SUBCOMMITIEe QUESTIONAIRE 6-11. Compare, however, his statement that a suit against "a governor, a secretary of agriculture, a mayor . . . or any other individual is not only acceptable and tolerable . . . [but] desirable." Rumsfeld, Legal, Peaceful and Responsible Way, 29 LEGAL AID BRIEFCASE 111, 112 (1970).

14. See text accompanying notes 85-86 infra.

15. Personnel changes, the firing of the Legal Service Director and Deputy Director by the OEO Director in Noveinber 1970, seen to have been associated with the effort to accomphish these administrative changes. See N.Y. Times, Nov. 21, 1970, at 1, col. 4. It has been argued that these discharges were part of an administration attempt to convert OEO into a "holding operation." Branch, The Ordeal of Legal Services: How the Poor People Won in Court But Lost in OEO, THE WASHINGTON MoNTHLY, Jan. 1971, at 3, 20. 
of the changes considered would have given greater control over legal services to non-lawyers within OEO, personnel whose primary responsibilities in connection with community action programs brings thein into close relationship with state and local officials. Because the proposed changes may be seen as responses to the aggressive strategies adopted by some local legal service programs-and particularly to those which entail challenges to state and local programs in welfare, housing, and other areas - an inquiry into the nature of aggressive legal service strategies is appropriate. The purpose of this Article, then, is to describe the kinds of activities now being carried on within the legal services programs, to compare these with the kinds of services offered by lawyers in other settings, and to express my conclusions as to the the kind of legal services program that the legal profession ought to support now and in the future.

\section{I}

\section{The Legal Services Program}

Let us first describe the magnitude, functions, and operations of OEO-funded legal service offices in broad terms. Financially, the program has been among the most modestly supported of all the OEO programs. Currently, funding is at the annual level of about $\$ 54$ million. ${ }^{10}$ This sum supports administration of the program and 260 neighborhood legal service grantees operating 850 neighborhood law offices staffed by 1850 full-time lawyers and 350 "Reggies" 17 in 49 states. $^{18}$ If the quality of the legal service offered to the poor is really a serious national concern, the inference seems warranted that either greater resources unust be introduced or much more severe rationing must be resorted to. In 1968, for example, a case load of 282,000 cases was handled by 1,800 lawyers (unore than 156 cases per lawyer) at an average cost of $\$ 168$ per case. ${ }^{19}$ A large percentage of these cases necessarily had to be disposed of on an assembly line basis.

The legal entanglements of the poor are not amenable to artless lawyering. One major area in which the poor use legal services is in dealing with family law problems. Poverty can distort human relationships; hopelessness and abortive efforts to cope with delinquencies of various kinds incessantly give rise to nuarital, juvenile, and other family

16. SUBCOMMTTTEE QUESTIONAIRE 6-7.

17. "Reggies" are young lawyers recruited into the legal services program through Reginal Herber Smith Fellowship awards funded by OEO. The program is discussed in Bramberger, Reflections on Legal Services for the Poor, 25 LEOAL AID BRIRFCASE 194, 195-96 (1967).

18. SUbCOMMITTEe QuestionaIRe 6-11.

19. 1968 OEO ANN. REP. 13. 
problems, often of a serious nature. ${ }^{20}$ Even if dealt with on the basis of legal standards responsive to middle-class norms, the family law problems of the poor are likely to be at least as complex as those of the middle-class chent. This alone marks an average cost figure of $\$ 168$ per case as inadequate. But an adequate response to the family problems of poor clients may often require far more than is called for in the case of a typical middle-class client. Divorce, separation, custody, adoption, and other matters may call for a different analysis and a different response where the clients live in a poverty setting than where they live in relative affluence. The lawyer handling these cases may find himself pressing for novel judicial responses. More lawyering, not less, will often be essential.

In other areas the imdications are similar. More than 25 million poor Americans ${ }^{21}$ are profoundly dependent on the fair and accurate administration of convoluted welfare, relief, and other aid regulations which give rise to issues of statutory construction, administrative procedure, and constitutional law. It is possible to ignore these kinds of legal issues; they were ignored for years. But we are deluding ourselves if we beheve that they can be adequately handled at modest cost per case. Again, the poor face an endless housing crisis and attendant problems with landlords, public and private. ${ }^{22}$ These involvements give rise to statutory, common law, and constitutional issues as to which cohesive rules are just beginning to be developed. Sinilarly, the poor are a source of income to sellers of goods and purveyors of credit, who may structure "deals" which the poor often must either take or go wanting. ${ }^{23}$ Responding effectively to these kinds of problems may require elaboration of broad provisions of the Uniform Commercial Code, tight analysis of truth-in-lending and other consumer protection statutes, or innovative proceedings before the Federal Trade Commission or state agencies. In short, the day-to-day problems with which the poor must live are likely to generate problems that, if treated as legal problems at all, cannot

20. See, e.g., Paulsen, Juvenile Courts, Family Courts, and the Poor Man, 54 CALIF. L. REV. 694 (1966).

21. The poverty level and the number of people who are poor are both indeterminate. In reporting ou the Economic Opportunity Amendments of 1969, Pub. L. No. 91-177, 83 Stat. 827, amending 42 U.S.C. $\$ \$ 2701$ et seq. (1964; Supp. V, 1970), the Senate's Labor and Public Welfare Committee accepted \$3,553 per year as the minimum income needed by a nonfarm family of four to live above the poverty level, and accepted $25,400,000$ as the approximate number of Americans living in poverty. S. Rep. No. 91-453, 91st Cong., 1st Sess. 2 (1969).

22. See, e.g., PRESIDENT's COMM'N ON URBAN Housing, REPORT (1968); National Comm'n on Urban Problems, Report (1968).

23. See generally D. Caplovitz, The POOR Pay More (1963); Dunham, Consumer Credit Problems of The Poor, in NATIONAL CONFERENCE ON LAW AND POVERTY, Proceedings 9 (1965); President's Panel on Consumer Education for Persons WITA LIMTEED INCOME, REPORT (1965). 
be intelligently dealt with except through lawyering of the highest caliber. If quality legal services is a serious goal, one must expect higher costs per case in this area than encountered for other client groups.

Statistics on the nature of legal service case loads and the ways in which cases are disposed of are of limited lielp in developing a picture of the way legal services business is actually handled. Statistical categories are necessarily broad and fail to signify differences in intensity. Moreover, poverty law offices vary widely in orientation and quality. Even within a single office one may find two very different orientations-for example, one young lawyer working solely on a few seemingly significant test cases and another older lawyer with an old-line legal aid background devoting himself to a leavy, service-oriented case load, involving, perhaps, a large number of uncontested divorces, suits for child support, and the like, all of whicl are handled in methodical, but conventional, ways. Still, the available data supports the impression that at current funding levels many of the legal problems of poor chents must be liandled in a perfunctory way. A major deficiency in the conventional legal aid approach was that massive caseload pressures allowed only limited, routine service. While it was hoped that OEO funding would make better service generally available, the statistics suggest that this goal remaims a long way off. OEO-funded neighborhood legal service offices carry caseloads that are very similar in terms of subject matter areas to those that have for many years been carried by oldline legal aid offices; while OEO-funded offices are somewhat more prone to litigation, cases are, by and large, disposed of in similar ways by each type of office. ${ }^{24}$

It may be, then, that OEO has been successful in stimulating a more vigorous and aggressive professional posture among legal service lawyers than is found in the traditional legal aid setting. There seems little doubt that several of the OEO-funded programs in major metropolitan areas on the east and west coasts, a few of those in the Midwest, and programs like California Rural Legal Assistance are performing not only aggressively, but effectively and imaginatively. ${ }^{25}$ Many of these major programs have large, able law reform units which initiate test case hitigation. Yet, many sunaller offices, and some large ones, continue to function in more conventional ways.

24. The basic source for data on legal aid services is E. BRownelL, LegAL AID IN THE UNITED States (1951, Supp. 1961). Statistical studies contrasting the work of the OEO-funded neighborhood legal service offices and the work of conventional legal aid offices suggest that caseloads and categories of cases are generally similar, but that $O E O$ offices may dispose of somewhat more cases by litigation and somewhat fewer by advice only. See S. LeVitan, The GREAT Society's Poor LAw 177-89 (1969); Stiegler, All for the Sake of Statistics, 28 LEGAL AID BrIEFCASE 101 (1970).

25. See, e.g., Address by Earl Johnson, Jr., supra note 13. 


\section{II}

\section{LAW Reform AND Legal SeRVICES}

In 1967, Earl Johnson, then Director of the Office of Legal Services, marked law reform as the priority goal of the program. ${ }^{26}$ He called for a concerted effort among poverty lawyers to identify legal issues having significant impacts on the poor as a class and to change the law through carefully prosecuted test cases and through drafting of and support for new legislation. Deliberate efforts have since been made by the Office to turn the program toward these ends. Encouragement has been given to all such undertakings already being carried on by funded local units. Wide publicity has been given to these so-called reform activities. Guidelines and other publications have exhorted all funded offices to adopt this kind of an approach. ${ }^{27}$

Some success has been achieved by those legal services attorneys who have climbed out from under the caseload and focused their attention on major problems. For example, when the Attorney General and OEO jointly convened a Conference on Poverty Law five years ago, crucial problems in the welfare area were summarized as follows:

Rulings have not always appeared humane or rational: aid is denied to families with more than one illegitimate child; homes are classified as "unsuitable" where an illegitimate child has been born after assistance began; "enployable" mothers are required to leave their children to the care of others and go to work; benefits are terminated on finding a "man in the house" regardless of his status or contribution to the support of the family; aid is refused newcomers who immigrated from other states without a "definite plan of support." 28

Today, through test cases brought by poverty lawyers, residency requirements for welfare recipients have been declared unconstitutional, ${ }^{29}$ and both the "man-in-the-house" rule ${ }^{30}$ and the "employable mother" rule ${ }^{31}$ have been invalidated. Again, in dealing with housing problems the conference participants focused upon retaliatory evictions against tenants for complaining about housmg code vioaltions. ${ }^{32}$ Today, through

26. Id.

27. As recently as May 1970, Donald Rumsfeld, then director of OEO, conceded the need for law reform activities of legal services lawyers. $\mathrm{He}$ informed a congressional subcommittee that one of the purposes of the legal services program was "[u]se of the judicial system and administrative process to effect changes in the laws and institutious which unfairly and adversely affect the poor." SUBCOMMITIEE QUESTIONAIRE 7.

28. National Conference on Law and Poverty, Report 30-35 (1965).

29. Shapiro v. Thompsou, 394 U.S. 618 (1969).

30. King v. Smith, 392 U.S. 309 (1968).

31. Anderson v. Burson, 300 F. Supp. 401 (N.D. Ga. 1968).

32. NATIONAL CONFERENCE ON LAW AND POVERTY, supra note 28, at 12. 
the efforts of poverty lawyers, decisions declaring such evictions to be invalid have been obtained in some jurisdictions. ${ }^{33}$

The Office of Legal Services has tried in a number of ways to encourage even more law reform activity. The best of these has been the back-up center, an approach that grew out of the experience of the privately endowed Center on Social Welfare Policy and Law at Columbia University. ${ }^{34}$ The Center, now funded by OEO, was established in 1965. It drew upon the resources of the school of social welfare, the law school, and other departments at Columbia to introduce a novel element into the welfare system: critical scrutiny of the substantive content and the administration of the system by skilled professionals committed to the interests of the poor. The Center developed legal materials on such issues as residency requirements, substitute father rules, search and investigation practices, family grant maxima, use of penal measures to impose behavioral constraints on recipients, and fair hearing procedures. ${ }^{35}$ The major successes, noted earlier, ${ }^{36}$ that have thus far been achieved by poverty lawyers in attacking welfare practices zeroed in on problems the Center had studied. Many of these successes can be traced directly to the output of the Center.

Encouraged by the success of the Welfare Center, the Office of Legal Services began to engage the resources of other universities in other subject matter areas. A back-up center was funded at Boston College to study consumer law problems, at the University of California at Berkeley to deal with housing and economic development issues, at Harvard to focus on legal issues affecting education of the poor, and at the University of California at Los Angeles to study law relating to health problems of the poor. ${ }^{37}$ While the form and scope of these operations have varied somewhat from campus to campus, the basic concept is the same for all.

It is too early for a final assessment of the value of the back-up centers and their contribution to increasing the quality and significance of local legal services. Output has varied, partly because some of the centers have been operating for longer periods than others, partly because

33. E.g., Edwards v. Habib, 397 F.2d 687 (D.C. Cir. 1968); Hosey v. Club Van Courtlandt, 299 F. Supp. 501 (S.D.N.Y. 1969); Portnoy v. Hill, 57 Misc. 1097, 294 N.Y.S.2d 278 (Binghamton City Ct. 1968).

34. The history of the Center is reviewed in Note, Beyond The Neighborhood Office-OEO's Special Grants in Legal Services, 56 GEo. L.J. 742, 756-60 (1968).

35. See Center on Social Welfare Policy and Law, 1967-68 Proposal 7 (1968); Center on Soctal Welfare Policy aNd Law, Report and Prospectus (1967).

36. See note 5 supra.

37. OEO, Memorandum to Legal Services Project Directors re Back Up Center Pamphlet, Sept. 11, 1970. 
some work is in more tractable subject matter areas than others, and partly, no doubt, because of differences in the congeniality of their university settings and in the quality of and priorities adopted by center leadership and personnel. Yet there is little doubt that, if adequately supported, the centers may in time help to diffuse among poverty lawyers generally elements now found only in the best of the local programs: comprehensive investigation; thorough analysis of fact, law, and policy; and careful planning of a sequence of responses.

\section{III}

The Housing and Economic Development Law Project: A CASE Study

The activities of the Housing and Economic Development Law Project, housed in the School of Law of the University of California at Berkeley, afford an opportunity to examine in some detail the role of the back-up center in promoting and supporting the law reform activities of local legal service offices. This, in turn, should facilitate a better understanding of the law reform aspect of the legal services program.

The first grant to the Housing and Economic Development Law Project was announced in August 1968. Initially, the Project focused attention upon four areas: slum housing and private landlord-tenant relations, public housing, FHA programs, and urban planning and redevelopment programs. ${ }^{38}$ Later, economic development programs for poor communities were added as another major area for study. ${ }^{39}$ In each of these areas the Project has sought to comprehend the social, economic, and legal interrelationships affecting the poor, to identify how existing law or public policy adversely affects the poor, to identify feasible changes in law and public policy that would provide significant gains for the poor, to work out strategies for legal action that would maximize the chances of obtaiming these changes, and to find efficient ways of assisting local legal service offices to implement these strategies on behalf of their clients. Further, the Project has sought ways to make the social and economic problems of the poor more visible in order that political and governmental processes will be compelled to deal with them. Finally, the Project has attempted to catalyze the organization of poor clients around problems that can be dealt with through the kinds of interventions that lawyers are skilled at providing. The purpose here is not primarily to evaluate the soundness of any

38. 1 National Housing and Economic Development LaW Project AnN. REP. (1968).

39. 3 National Housing and Economic Development Law Project Ann. REP. (1970). 
strategies developed by the Project, nor is a comprehensive review of the full range of Project activities here undertaken. The aim, rather, is to disclose the nature and character of selected Project functions that typify the aggressive kind of lawyering now to be found in some legal services programs.

\section{A. Activities in the Private Sector}

The work of the Project has spanned a wide range in dealing with privately owned slum housing. Initially, it sought ways to upgrade the quality of local legal service lawyering in connection with summary eviction proceedings, a major litigation category in many local offices. Manuals were prepared and disseminated discussing the range of possible procedural defenses to summary eviction-defenses which are often the key to successful negotiations. To give one example, the idea that housing code violations might be a defense to eviction proceedings had been discussed in poverty law circles for several years, but no local legal service office had fully developed it. Drawing upon several diverse legal theories, the Project prepared model materials to argue that by reason of significant code violations a property owner lost his right to utilize summary eviction proceedings. ${ }^{40}$ Other Project activities in the landlord-tenant area have included preparation of analytical and practice-oriented materials on "slumlordism" as a tort, ${ }^{41}$ rent withholding, and receivership statutes. Local legal services lawyers, with the assistance of and inaterials prepared by the Project, are beginning to move the law of landlord and tenant out of the grip of 19th century caveat emptor concepts. ${ }^{42}$ Additionally, the Project has assisted legal services lawyers in drafting and sponsoring modern legislation.

The Project has also studied the emerging area of tenant unionism: efforts have been made to identify the particular kinds of situations where this strategy shows promise of working; tenant management techniques and problems have been canvassed; potential strategies for tenant organizations have been evaluated from the legal and the practical perspectives. The Project not only disseminated materials among local legal service offices ${ }^{43}$ but conducted workshops and provided staff lawyers as consultants to local offices seeking help. Very recently, model

40. These and other materials prepared by the Project for local legal services offices are published by Prentice-Hall, Inc., in National. Housing and Economic DeVELOPMENT LAW PROJEcT, HANDBOOK ON HousING LAW (1969) [hereinafter cited as Project HANDBOOK], a two volume looseleaf manual coinprehending the area of housing and development law and public and private landlord-tenant law.

41. See generally Sax \& Hiestand, Slumlordism as a Tort, 65 MICH. L. REv. 869 (1967).

42. See cases cited note 6 supra.

43. 2 PRojEct HaNdBook ch. I, at 7-127. 
legislation dealing with landlord-tenant collective bargaining has been prepared and analyzed.44 Because of these Project activities, legal services lawyers have been armed with the technical know-how essential to the effective use of tools which, in some settings, have great potential for the achievement of significant gains for the poor. In circumstances where tenant organization is feasible and landlords operate as professionals on a significant scale, impacts can be made upon a number of problems concerning poor clients: housing quality and maintenance, the absolute level of and interrelationships among rental rates, the level and quality of services, eviction practices and procedures, and so on. Tenants, moreover, are given a sense of participation in decisions that have important consequences upon the quality of their lives.

\section{B. Activities in the Public Sector}

In dealing with public housing, the Project has performed comparable functions. Of particular interest is a strategy built around the modermization prograin sponsored by the Department of Housing and Urban Development. ${ }^{45}$ Under this program, HUD made funds for upgrading the physical condition and managenent policies of public housing units available to local housing authorities. ${ }^{46}$ The Project informed legal services attorneys about the program's details and developed a strategy to enable the tenants to develop their own analysis of physical and managerial inadequacies. Through this approach, as in the case of successful tenant umion activities, poor chents could be given an opportunity to affect decisions important to thein, and in addition, resources allocated by HUD to their needs could be channelled into those specific areas of deepest concern to the intended beneficiary group. Legal services attorneys using this strategy have focused upon managerial as well as physical modernization. Responding to the interests of poor chents, they have pressed, in many cases with considerable success, ${ }^{47}$ for the establishment of grievance procedures, specification of grounds for eviction, prior notification of inspections, and recognition of tenant representatives for continued negotiation on these and related matters.

44. The Project study is published as Moskovitz \& Honigsberg, The Tenant Union-Landlord Relations Act: A Proposal, 58 GEO. L.J. 1013 (1970).

45. 1 PROJECT HANDBOOK ch. IV, pt. VI, at 2-27.

46. The provisions of the Modernization Program, promulgated pursuant to Low Rent Housing Act $\$ 8,42$ U.S.C. $\$ 1408$ (1964), are set forth in HUD, Low Rent housing: The Modernization Program Handbook 1 (RHA 7485.1, June 1969). The program is intended to assist local housing authorities in "upgrading those low-rent housing projects which, for reasons of physical condition, location and outmoded management policies, adversely affect the quality of living of the tenants." 'Id.

47. See A. Hirshen, The hUD Modernization Program 22-26, passim (National Legal Aid and Defender Ass'n Monograpli No. 4, 1970). 
The Project has also prepared and distributed to local poverty law offices analytical materials, comparable to those discussed in connection with private housing, concerning management standards and procedures in public housing. ${ }^{48}$ Areas covered include tenant selection, eviction, and rental rates. Local legal services offices have been encouraged to engage concepts of substantive and procedural fairness in dealing with these matters, which were previously thought subject to the unreviewable discretion of the manager hired by the local housing authority. ${ }^{40}$

Of equal importance, the Project has acted, in effect, as Washington counsel for the poor in connection with pubhic housing issues. It has prepared model public housing lease provisions ${ }^{50}$ designed to give public housing tenants the kinds of contractual protections against arbitrary pubhic landlord action that any lawyer would seek to obtain for his chent under a negotiated private lease. Working closely with the National Tenants Organization, the Project has presented these model provisions to the Department of Housing and Urban Development, and has persuaded that department to promulgate regulations requiring that several of the model provisions be included in leases used in all federally assisted pubhic housing. ${ }^{51}$ Most recently, HUD implemented Project-recommended regulations requiring local authorities to provide procedures for tenants to obtain representation and to deal with tenant representatives. ${ }^{\sigma 2}$

The Project has also received numerous requests to assist in drafting legislation of interest to the poor, such as the Brooke Amendment to the Housing Act, ${ }^{53}$ and to comment on pending legislative proposals. It was also invited to participate in a conference of top level officials to discuss basic administration strategy in dealing with urban problems. ${ }^{.4}$

These efforts have yielded some subtle values beyond substantive changes in lease provisions. HUD hearings have brought together

48. 1 Project HandBook ch. IV, pt. V, at 3-46.

49. See, e.g., Holmes v. New York City Housing Auth., 398 F.2d 262 (2d Cir. 1968); Vinson v. Greenburgh Housing Auth., 29 App. Div. 2d 338, 288 N.Y.S.2d 159 (1968).

50. 1 Project HaNdBooK ch. IV, pt. VII, at 2-53.

51. Prohibition of Certaiu Provisions in Low-Rent Public Housing Leases, HUD Circular No. RHM 7465.6 (Aug. 10, 1970).

52. The Project's proposals to HUD appear in 1 ProJect HaNdBook ch. IV, pt. $\mathrm{V}$, at 3-37. The new HUD regulations responding to these proposals are set forth in Grievance Procedures in Low-Rent Public Housing Projects, HUD Circular No. RHM 7465.9 (Feb. 22, 1971). For press coverage of the Project's efforts and HUD's response, see N.Y. Times, Nov. 16, 1970, at 12, col. 1; id., Feb. 24, 1971, at 1, col. 7. 1970).

53. Housing and Developinent Act of 1969, $\S 211,42$ U.S.C. $\S 1424$ (Supp. V,

54. The conference, working under an agenda entitled "Strategic Urban Decisions of the 70's," was held at Airle House iu Warrenton, Virginia, on August 6, 7, and 8, 1970. The Project argued against heavy reliance upou a dispersal policy, which empha- 
representatives of such diverse groups as the National Association of Real Estate Boards, the National Association of Housing and Redevelopment Officials, the United States Conference of Mayors, the National Association for the Advancement of Colored People, and the National Tenants Organization. Through these sessions, problems encountered in public housing administration have been aired in structured settings with focus upon concrete proposals for change. All of the various participants in the process of financing, building, managing, and living in public housing have developed greater understanding of the needs, interests, and motivations of others who participate; a climate more conducive to significant responses to long-ignored needs has been created. ${ }^{55}$

\section{Development of Complex Strategies}

The overall utility of efforts such as those described above are difficult to gauge. The direct costs of supporting the Project have been modest. ${ }^{50}$ But most of the Project's efforts are aimed at upgrading the quality of local legal services in the housing area, and to the extent that the Project is successful, it diverts local legal service resources from one kind of deployment to another. A number of the Project strategies outlined above seem simple, efficient, and effective; even the smallest local offices can substantially improve their performance by assigning one attorney to familiarize himself with the Project's materials. But a few Project strategies are highly complex; to be utilized at all, these demand a heavy commitment of time from skilled personnel within the local offices.

A threshold question is whether a particular local office has lawyers on its staff whose interests and skills make it feasible to pursue a complex strategy. At best, substantial time may have to be spent in developing new skills and gathering information both about applicable Jaw and policy and about local programs and conditions. In general, this has been feasible in the larger programs in major urban areas; with few exceptions, smaller offices have been ill equipped to utilize coinplex stra-

sizes new towns and related concepts in the hope of stimulating migration and integration of the poor into suburban communities where conditions might be better. Instead, it urged the administration not to ignore the festering housing problems of the poor in the urban centers where they now reside. See generally Alonso, The Mirage of New Towns, PUBLIC INTEREST, Spring 1970, at 3.

55. The results of these meetings, from the point of view of local development officials, is summarized in National Ass'n of Housing and Redevelopinent Officials, NAHRO's Role in the Developnient of a Model Lease and Grievance Procedures for LHA's, Dec. 21, 1970. While noting points of disagreement with the Project and various tenant groups, this release enuphasized areas of accord. See, e.g., id. at 2.

56. OEO Grants Nos. CG-8530 A/O and CG-8416 to the University of California provide the Project with support for a professional staff consisting of 12 lawyers, a planner, and a political scientist. 
tegies. Even assuming legal service resources are available in a given program for deployment to a complex housing strategy, the question must be asked: What are the likely pay-offs and what are the lost-opportunity costs incurred in undertaking a complex strategy?

The level of sophistication in legal services lawyering that some Project strategies demand can be demonstrated by a review of some of the work which has been done in connection with urban planning and development programs. In any urban area, the range of public planning and development activity going on at any given time is likely to be both vast in amount and complex in form and impact. Typically, it will include highway development, public clearance and redevelopment programs (primarily in downtown areas), conservation and rehabilitation projects, code enforcennent projects, perhaps the development of some public housing, and programs for rebuilding or improving public facilities as varied as sewage treatment plants and public office buildimgs. The quality of the planning and administration that informs these programs varies enormously from area to area and even among separate municipalities within the same urban region. Though the values informing local decisions have often been multidimensional, major ingredients have typically included desires to stimulate the local economy and to relieve local tax pressure by increasing the tax base and decreasing service costs. Though inuch of the federal grant-in-aid legislation through which such programs are supported is intended to aid the poor, ${ }^{67}$ the interests of the poor have in many cities been paid scant heed..$^{68}$

It is not merely that programs aimed at responding specifically to the needs of the poor have been rare. Far worse than this, developinent programs have often imposed enormous burdens upon the poor. When an urban expressway is designed, it may be laid out so as to spare the best urban property, whicli would be nost expensive and economically wasteful to acquire, and which would reduce the tax base most significantly. As a result, an urban expressway may cut a wide swath through areas of old, low-cost housing, substantially reducing the housing stock available to the poor; cohesive minority group communities may be destroyed, and uncompensated hardships placed on poor families forced to inove without adequate relocation assistance.

Urban redevelopment projects may have similar impacts. Though purportedly aimed at slum clearance and the provision of better housing, such projects inay actually be designed to clear areas of old, low-cost housing in order to make way for commercial, industrial, or luxury hous-

57. Oeo, Catalog of Federal Assistance Programs (1967), lists 459 federal aid programs designed in whole or in part to aid poor Amerieans.

58. The literature diagnosing these problems is enormous. For a representative collection of papers, see The URBAN CondrTion 97-200 (L. Duhl ed. 1963). 
ing uses. Though federal aid for these projects is subject to the statutory condition that there be a feasible plan for relocating displaced families in sound housing, ${ }^{59}$ many relocation plans have in fact been grossly inadequate and, at times, transparent shams. ${ }^{60}$ So with the whole range of public development programs: housing code enforcement may displace more families than it helps; public improvement programs may focus on the needs of the business community and the middle class instead of the poor. Often, the urban poor are politically weak and their interests ill-represented in decisionmaking processes at the local level.

\section{Development of a Comprehensive Approach}

Efforts by poverty lawyers, often with Project assistance, to deal with these kinds of problems in connection with single development proposals have had some success. ${ }^{61}$ The Project, however, set for itself the goal of developing a compreliensive approach that might be used to force municipalities to come to terms with the housing needs of the poor in connection with all public development activities. The approach recognizes that a lousing crisis for urban poor is the result of a complex set of interactions, but asserts that one element which, over time, has a significant impact (whether to alleviate or deepen the crisis) is the direction and thrust of public developinent investment. The task was to identify legal requirements through which legal services lawyers representing poor residents might be able to influence significant decisions by cities as to the allocation of resources devoted to development. The compreliensive strategy ultimately developed ${ }^{62}$ was predicated upon the workable program requirement of the Housing Act of $1954 .{ }^{63}$

The 1954 Act imposed as a condition of federal aid to municipalities for public housing redevelopment and renewal that the city

59. Housing Act of 1949, § 100, 42 U.S.C. $\$ 1450$ (1964).

60. See S. Greer, Urban ReNewal and American Cities 56-64, 70-73, 91-97, 101-10 (1965); Fried, Grieving for a Lost Home, in THE URBAN CONDITION 151 (L. Duhl ed. 1963); Gans, The Human Implications of Current Redevelopment and Relocation Planning, 25 J. AM. INST. Planners 17 (1959). Now that relocation plans are judicially reviewable, inadequacies are beginning to be demonstrated in court. See cases cited note 61 infra.

61. For example, in a number of crucial cases courts have enjoined redevelopment projects upon a showing that the relocation plan for displaced residents was inadequate. E.g., Tenants \& Owners in Opposition to Redevelopment v. HUD, Civil No. 69324 (N.D. Cal., Apr. 30, 1970); Western Addition Community Org. v. Weaver, 294 F. Supp. 433 (N.D. Cal. 1968). 5-53.

62. The strategy is set forth in detail in 1 Project HaNDBook ch. II, pt. I, at

63. Housing Act of 1954, $\$ 303(c), 42$ U.S.C. $\S 1451$ (c) (1964); see Rhyne, The Workable Program-A Challenge for Community Improvement, 25 LAw \& CoNTEMP. PROB. 685 (1960). 
prepare and regularly revise a "workable program" for community renewal. ${ }^{64}$ The workable program was to provide for code enforcement, comprehensive planning, and inspection to identify developing blight. Most importantly, it was to utilize a suitable administrative organization, to specify the financial resources devoted to implementing it, and to provide for relocating displaced residents in safe and sanitary housing.

Though this statutory provision obviously envisaged comprehensive local efforts to attack deteriorated housing as a condition to federal redevelopment aid, the provision was for years under administered. Until 1969 any city ready to cope with the necessary paper work could as a practical matter provide HUD with a thin, statistical veneer suggestive of study and planning and thereby qualify for aid. ${ }^{65}$

Though probably not intended to represent significant substantive changes, new HUD guidelines for the workable prograin indicated that to retaim eligibility for aid $^{60}$ nunicipalities were required to submit a workable program every two years showing the status of municipal activity in four areas: planning, citizen participation, code enforceinent, and housing and relocation ${ }^{67}$ A city was to identify inajor problems in each area and show specifically what it was doing to cure them. The Project saw the substantive and citizen participation requirenents spelled out in these new guidehnes as affording an opportunity for broad cliallenges to municipal planning and developinent programs that dealt harshly with the poor. Project lawyers also saw the guidelines as providing substantial leverage: if HUD were persuaded to deny certification to a deficient program, the statutory sanction would be to cut off the flow of federal funds to the city.

Though reasonably simple in concept, the workable program strategy is highly coinplex in implementation. The strategy received one of its first full-scale tests in San Francisco, where for a variety of reasons, the potential for success seenred high. Let us look at that experience. ${ }^{.8}$

In 1969, the housing situation of the poor in San Francisco was much the same as that in nost large American cities-quantitatively and

64. Housing Act of 1954, $\$ 303$ (c), 42 U.S.C. $\$ 1451$ (c) (1964). 101-10.

65. 1 PROJECT HANDBOOK ch. II, pt. I, at 11-12; S. GREER, supra note 60 , at

66. Covered grant-in-aid programs include the Urban Renewal Program, the Neighborhood Development Program, the Concentrated Code Enforcement Program, the Interim Assistance for Bhighted Areas Program, the Demolition Grant Program, the Community Renewal Program, and the General Neighborhood Renewal Program. 1 Project HANDBOOK ch. II, pt. I, at 13-14.

67. See HUD, Workable Program For CommUnity Improvement ii-iii (1968).

68. The description which follows of the workable program strategy in San Francisco draws upon M. Bozeman, San Francisco and the Workable Program: A Case Study, May 2, 1970 (unpublished paper, National Housing and Economic Development Law Project), and upon interviews by the author with the Project attorneys. 
qualitatively inadequate. ${ }^{69}$ Over time, development decisions had tended to inake the problems even more severe. Nonetheless, the city was one where it appeared that the Project's proposed strategy might be productive. San Francisco's workable program was about to come up for HUD review. The city was served by a legal service foundation that had succeeded in attracting skilled and imaginative lawyers and that had had considerable experience in dealing with development issues. Community organization in ghetto areas was strong, aggressive, and vocal, yet ready to work "within the system" for constructive change. The city, moreover had reason to respond constructively to claims made by legal service lawyers in behalf of poor residents. Legal service lawyers, assisted by Project attorneys, had already had significant success in forcing the city to meet its obligations under federal law: two major urban renewal projects had been halted by federal court decrees on the ground that they failed to meet statutory prerequisites for an acceptable plan for the relocation of displaced families in safe and sanitary dwellings. ${ }^{70}$

In this setting, the workable program strategy was implemented by Project attorneys working with local legal service lawyers. Clients who resided in areas adversely affected by redevelopinent decisions (some of whom had been parties to the earlier litigation) were advised about the strategy and its potential for forcing the city to come to terms with housing needs on a comprehensive basis. Gradually, with the encouragement of Project attorneys, a city-wide coalition of community groups was put together. The group came to be known as the San Francisco Task Force for a Workable Program. It was far broader than a coalition of leaders from organizations within the poor and minority communities: it also included clergymen, planners, architects, and lawyers, some of whom enjoyed a degree of local prominence and all of whom possessed good credentials for civic activity. As this coalition was built, substantial time was spent by Project attorneys explaining the requirements of federal law and their potential, discussing tactical issues, and generally counselling the emerging community organization.

The Task Force sought initially to participate in the preparation of the city's new workable program that was to be submitted to HUD. Task Force members were given audience with a subcommittee of the Board of Supervisors and with the Mayor, but failed to obtain any commitment either that they would be consulted or allowed to participate. A Task Force subcommittee nevertheless went to work, drawing upon the housing, architectural, planning, and legal experts brought to-

69. The most comprehensive available study of development processes in San Francisco is Arthur D. LitTle, Inc., Community Renewal Programming (1966).

70. See cases cited note 61 supra. 
gether in the group. The city's prior workable program was analyzed and deficiencies between promise and performance were noted. A detailed set of proposals for housing code changes and for a code enforcement program were worked out. These were predicated on low interest improvement loans, which would facilitate bringing deficient property up to liveable levels, rather than upon rigid enforcement, which might remove property from the dimmishing housing stock. Planning and programming proposals were also prepared. Throughout, Project attorneys drafted documents, gathered information, and consulted as to goals and policy, coordinating the work of Task Force members. While this work went on, several meetings were held with representatives of city departments who were preparing the city's workable program. Some city officials were very responsive, and meetings were in some instances informative and congenial. Others, as might be expected, were less ready to engage in dialogue with the Task Force. Generally, a Project lawyer or a local legal service lawyer was responsible for Task Force presentations at these sessions.

By midsummer, Task Force efforts that had begun late in the spring eventuated in a coinprehensive set of proposals. Ainong the responses called for were: providing substantial additional low-rent units in those redevelopment areas that had earlier been stalled by litigation; halting all displacements in connection with public construction until adequate relocation housing was available; centralizing all relocation responsibility in the Mayor's office; implementing a rental assistance program; providing low-interest loans to bring properties up to code; gathering comprehensive information, including data on deınolition and new construction and a vacant-land inventory; adopting a land use policy that will assure maximum use of available sites for housing. Other proposals included the creation of a housing developinent corporation, mitiation of a receivership program for renovation of below standard units, and an ordinance requiring that replacement units be available before any permit be granted for the demolition of housing for new private construction. Additionally, a number of procedural and planning proposals were made, as well as proposals for contimuing citizen participation in fashioning urban development policy. ${ }^{71}$

Efforts by the Task Force to induce the city to adopt its proposals as part of its new workable program took many forms, including consultation and negotiation with city officials, presentations to a city council committee and to the entire council, and efforts to mobilize opinion through publicity. None were successful. In winter 1969, the city

71. The Task Force expressed its views to city officials through meetings, memoranda, and letters. The most comprehensive summary of Task Force proposals appears in Citizens Emergency Task Force for a Workable Housing Policy, The Shame of SAN Francisco (1969). 
adopted its own workable program proposal. ${ }^{72}$ The document was a conventional one. It explained away past deficiencies, focused more on fiscal problems than on substantive needs, and qualified its commitments for the future, perhaps to reduce the risk that later performance would be found wanting.

When the draft workable program was made public, the Task Force published a highly critical document, The Shame of San Francisco, which was given wide coverage in the metropohtan press. ${ }^{73}$ While this effort both to document deficiencies in the city's program in a hardheaded way and, at the same time, to generate political support for a better program did not stimulate a significant response from the city, The Shame of San Francisco became the basis for an administrative complaint to HUD urging that the city's workable program be rejected. UItimately, in March 1970, HUD decided that the city's workable program was deficient, though correctable. In specifying the plan's shortcomings, HUD's notification to the city largely echoed the Task Force's basic coinplaints. ${ }^{74}$

While the long term effects of the Task Force's efforts are difficult to appraise, its leadership is convinced that it is having a significant, beneficial influence on the city's responses to the needs of the poor. In a report to its membership, the Clairman listed three major achievenents: improvements in the city's repair and demolition program; preparation by the city's planning department of an inventory of sites for public housing; and initiation of a housing improvement program calling for the funding of a housing development corporation, increased municipal rent assistance, and code enforcement designed to minimize displacement. $^{\text {75 }}$

The San Francisco scenario is fairly typical of those which are now being played out in such cities as New York, Chicago, Philadelphia, Los Angeles, Minneapolis, and Bridgeport, where the workable program strategy has also been invoked. In some of these cities responses comparable to that in San Francisco are being achieved at the municipal level. ${ }^{76}$ In at least one-Camden, New Jersey-hitigation is now in progress, ${ }^{77}$ and it is too early to assess results.

72. Ctry of San Francisco, Workable Program for Community ImproveMENT 1969-1971 (1969).

73. E.g., S.F. Chronicle, Nov. 24, 1969, at 1, col. 1.

74. Compare Letter from Samuel C. Jackson, Assistant Secretary of HUD, to Joseph Alioto, Mayor of San Francisco, Mar. 24, 1970, with Citizens EMERgency TASK FoRCE FOR a WORRARLe Housing Policy, supra note 71.

75. Report of William McCabe to members of the San Francisco Citizens Task Force for a Workable Housing Policy (undated, circulated in Winter 1970).

76. See Letter from Kenneth Phillips, Director of the National Housing and Economic Developinent Law Project, to Terry Lenzner, OEO, Aug. 11, 1970.

77. Camden Coahition v. Nardi, Civ. No. 1128-70 (D.N.J., filed Aug. 29, 1970). 
There is another less tangible gain to be found in efforts like the workable program strategy. One goal of law reform activity by poverty lawyers, and certainly of most major undertakings in the housing law area, is to make visible the too easily ignored problems of the poor. In the past, there has been a great deal of legislation, particularly at the national level, that in terms deals with real problems of the poor. But however well conceived, programs for the poor are usually inadequately funded. And many programs aimed at least in part at helping the poor become subverted in administration to other ends; redevelopment and renewal are, perhaps, prime examples.

Efforts like those in San Francisco are unlikely, of themselves, to signifcantly increase the housing stock. But they can draw the problems of the poor into the mamstream of urban decisionmaking. They force officialdom at the local and national levels to face the problem, assess it, and either respond to it or deliberately refuse to do so. They also engage a degree of interest in opinion-forming media, obviously an important element in the political processes that affect urban life. They inhibit the opportunities of society as a whole to dissemble about what it is doing for or to the poor; they deprive those in public life of the pretense that serious problems are being seriously met merely by passing statutes which are either under funded or distorted in adıninistration.

Political force invites political reaction. Reactions have been generated here in the form of efforts by municipal officials to induce HUD to water down workable program regnlations or to administer them less vigorously. ${ }^{78}$ It may well be that the workable program requirement will also be attacked in Congress. Yet even these responses inay be seen as processes through which evasion and pretense are ended. An important public issue is being thrust in explicit terms into forums where it will have to be faced and frankly decided; opportunities for sham responses to real problems are being reduced. And poverty lawyers, it may be hoped, will represent the interests of their clients in Washington, as well as at the municipal level; in any forthcoming legislative fight over the workable program requirement, the mumicipal lobby ought not to be the only one heard from.

\section{IV}

\section{Evaluation From A Professional Perspective}

Throughout this Article we have seen examples of the activities that typify the law reform efforts of legal services lawyers. These efforts can be evaluated in traditional terms by balancing the gams and costs

78. See San Francisco Cittzen's Task Force for a Workable Housino Policy, San Francisco's Workable Program One Year Later (1971). 
of the specific strategies and programs undertaken. Such an evaluation, however, would fail to take into account the independent value of fostering sophisticated lawyering in the local legal service offices themselves. I submit that providing the poor with an independent professional resource capable of highly sophisticated responses will intiate a process by which the poor, through their lawyers, will in time learn to link more effectively with society as a whole.

Highly skilled lawyers for the poor are a new but growing corps of professionals. As yet, they have few settled norms or standards, few tried and true professional responses. Poverty lawyers are only beginning to see the potential uses of independent legal services. Yet legal service strategies aimed at large impacts are already under political attack. The attack comes, primarily, from those concerned about suits by legal service lawyers against agencies of state, local, and federal government. ${ }^{79}$ Lawyers can, perhaps, contribute to the debate by viewing such legal service activities froin a professional perspective. Legal service lawyers do not represent the public; they do not represent agencies of government, state or federal. They are supported by the federal government to be lawyers for the poor. Unless it be assumed that the program ought not to provide capable and effective lawyers to the poor, the issue, then, is whether impact strategies used by legal service lawyers constitute good lawyering - that is, whether these activities represent the kinds of responses that capable and responsible attorneys who represent poor clients ought to be making, given the objectives of their chents, the possible ways of achieving those objectives, and the range of activities in which it is proper and feasible for a lawyer to engage.

As noted earlier, ${ }^{80}$ case disposition statistics indicate that even to-

79. See, e.g., Robb, Controversial Cases and the Legal Service Program, 56 A.B.A.J. 329 (1970), which warns that, without more vigorous support from the bar, the legal service program may not survive governmental resentment. Governor Reagan's controversial veto of a renewal grant to California Rural Legal Assistance provides an enlightening case study to test Mr. Robb's thesis. The veto was widely reported in the press as an attack on a legal services organization that had successfully challenged many of the Governor's own programs. See, e.g., N.Y. Times, Dec. 28, 1970, at 22, col. 3; S.F. Examiner, Dec. 27, 1970, at 1, col. 5. The veto is stated to be based upon "gross and deliberate violations of federal regulations," which are documented in Car. Office of Economic Opportunity, A Study and Evaluation of CaLifornia RuRal Legai Assistance, Inc. (1971). This 283 page report charges CRLA with affording criminal representation [id. at 158-67], disregarding chent eligibility standards [id. at 168-74], soliciting clients to stir up litigation [id. at 175-91], and otherwise failing to comply with the terms of its grant. CRLA, requesting an evidentiary hearing, has answered these charges in detail. CRLA, REPORT TO THE OFFICE OF ECONOMIC OPPORTUNTTY (1971). OEO has appointed a commission to study the disputed issues. See S.F. Examiner \& Chromicle, Feb. 7, 1971, This World (Magazine), at 5, col. 4, which reviews the history of the controversy. See also Arnold, Whither Legal Services, JURIS Docror, Feb. 1971, at 3.

80. See note 24 supra and accompanying text. 
day, half a decade after the legal service program was initiated, poverty cases of all types are likely to be disposed of either by consultation, negotiation, or litigation. This is a surprisingly narrow list. Lawyers representing other client groups routinely engage in a wide range of functions not comprehended by the three categories into which service for the poor seem so easily to fit. Efforts by the larger, better staffed, and more aggressive of the local legal services programs-efforts like those being developed, supported, and encouraged by the back-up centerscan fairly be characterized, therefore, as attempts to bring lawyering for the poor into the professional mamstream. To the extent these efforts are successful, they provide for poor clients legal services of high quality which conform to the best traditions of the legal profession.

What are the functions which, in general, lawyers may be expected to perform? An American Bar Foundation pamphlet describes the functions of the lawyer im general practice as follows:

The range of legal matters that private practitioners undertake is as broad as the law and legal institutions themselves. Private practitioners help form organizations-business corporations, trade groups and labor organizations, charitable iustitutions, clubs, and societies; they negotiate contracts . . . ; they devise . . . security devices . . . ; they negotiate and draft terms of settlement of legal disputes; they advise clients in connection with litigation and represent them in court and before administrative tribunals; and they "lobby" in the legislature. . . .

In his planning, the lawyer aims at arrangements that will achieve the client's immediate objectives, safeguard his larger interests, regularize the means by which his objectives are achieved, and prevent him from becoming embroiled in legal controversy. The lawyer in private practice is therefore not only an advocate, legal counselor, and a draftsman, he is also soinething of a busimess and political statesman, a managenent consultant, an ethical counselor, and a medium for form, order and cooperative activity. To an extent unparalleled elsewhere, the lawyer in private practive in the Umited States is intimately and pervasively involved in the management of his client's affairs. ${ }^{81}$

Few lawyers who have engaged in a conventional private practice would dispute these assertions. Lawyers in their conventional professional roles identify with their clients' interests and accept their clients'

81. American Bar foundation, The Legal Profession In the United States 9-10 (1965). See also Q. JoHNstone \& D. Hopson, LAWYers AND THEIR Work 77-130 (1967), which categorizes lawyers' tasks as follows: Advice; negotiation; drafting; hitigation; investigation; legal research and analysis; lobbying; acting as broker; public relations; adjudication; financing; property management; referrals; supervision of others; emotional support; acting as scapegoat; and business getting. 
basic objectives. They are result-oriented. They are analytical. Taking the basic structural elements of a problem context as given, a lawyer will seek to identify the constraints which are capable of being varied by techniques such as persuasion, the application of economic leverage, or the manipulation of legal or political institutions, and to work out ways of influencing these variables in order to achieve his client's goal or a near approach to it. This may take many forms. For example, it may mean persuading a businessman to take a particular course of action by developing a sense of his situation and his interests and negotiating with him with respect to these. It may mean finding someone with money to lend and inducing him to lend it. It may mean persuading a public agency to exercise its discretion in a particular way. It may mean bringing a number of previously independent parties together in some new concerted endeavor and designing the structure through which they will relate. It may mean drafting an ordinance and persuading a city council to enact it. It may mean bringing and winning a lawsuit. Narrowly perceived, the lawyer specializes in dealing with law and legal institutions-as counselor, as draftsman, and as advocate. But veiwed more broadly, and more accurately, he can be seen as designing and implementing techniques for affecting business, social, political, and legal intitutions in order to achieve results favorable to his chents. Even when he deals with legal norms directly, it is often in an effort to change them either legislatively or judicially. Thus, the so-called law reforn activities we have been discussing in reality amount to no more than providing the poor with the same kinds of professional services that private counsel have traditionally performed for those who can afford their fees.

There are those who would denigrate these wide-ranging functions, who would disdainfully label the lawyer a "hired gun." But at his best the lawyer is an activist who brings to his tasks a range of knowledge, experience, judginent, and sensitivity. The function he perforins is an essential element im dynamic social and economic growth and in orderly adjustment and change. The conventional American ideology includes the conviction that economic, social, and political power can and should be widely dispersed, and that orderly accommodations are possible between coinpeting and conflicting interests. The lawyer is an agent through whom power so dispersed can be exercised and through whom such accommodations can be achieved.

But let us advert again to the poor. If the conception lere developed of the lawyer and his role is an accurate one, should we not expect to find in the disposition statistics for legal services cases some categories in addition to the conventional ones: advice only, negotiation, and litigation? Surely there is no reason to suppose that the problems of other chents may often require the lawyer to draft new legislation and press for 
its passage, but that the problems of poor clients never will call for this response. Surely there is no reason to suppose that others engaged within the American legal and economic system will require assistance in planning and implementing a complex course of conduct, but that such services would be useless to the poor. Nor does it weigh against the prograin that lawyers who cliallenge government on behalf of the otherwise unrepresented are themselves funded by government. The stability of the American system, its ability to absorb stress, to cliange and grow, derives not alone froin its openness to self-correction, but also from the devices it lias developed and employed to facilitate internal checks and balances.

Viewed froin this perspective, the range of law reform activities being engaged in by many of the larger legal services programs and being stimulated by the back-up centers seems not only justified, but indeed essential. Many of these activities have had immediate substantive payoffs for poor clients. Others have made the problems of the poor and the weakness of social responses more visible. Most of them have at least tended to bring the poor closer to the mainstreain of society by giving thein and their lawyers experience in utilizing a fuller range of responses to real and pressing problems. All pass muster under any plausible test of professional responsibility: they are precisely the kinds of things that able and aggressive lawyers ought to be doing for the client group involved.

\section{$\mathrm{V}$}

\section{Legal Services Under ATtaCK}

If this analysis is correct, the legal services prograin has during its first five years been heading in the right direction. We should at this stage be finding ways to consolidate and deepen the gains that have been made. In addition to expressing concern about low funding levels, we ouglit to encourage further experimentation by the Office of Legal Services with institutional arrangements stimulating more effective lawyering. One very apparent problem is the limited ability or mclination of small local offices-indeed, even larger ones operated on the conventional legal aid model - to absorb and utilize many of the techniques being developed by the back-up centers. Perhaps the Reginald Heber Smith Fellowship Prograin could be used to enhance the capacity of some of these offices. Today, Reggies tend to be sent in numbers to the best of the local offices, to offices where they can learn most. Perhaps these highly skilled and dedicated young lawyers should, after a period of training, be assigned instead to offices where they will be opening up to their professional colleagues the potentials of law reform. Perhaps some of the better offices in urban settings could be given special grants 
to perform missionary work and provide consultant services to less vigorous offices in the hinterlands around the city where they function.

Yet as the legal services program has come of age, as it has grown stronger and increasingly successful, it has often received not greater support but more vigorous attack. State and local officials do not like to engage in the tedious exercise of hearing out irate elements of the citizenry. Most of them do not like being sued by their citizens. They like it even less when litigious citizens prevail against them and, in prevailing, bring to a lialt public programs of considerable scope and assumed importance. They seem to like it least of all when the litigation that frustrates them is supported by the federal government, which may also be funding the endeavor that they, the officials, are working to carry to its completion. These are natural and understandable responses. It becomes increasingly difficult to administer public programs as the society affected by them grows increasingly complex.

The result has been a heightened tempo of opposition to an aggressive, independent legal services program. This was first felt with force in the strong support for the so-called Murphy Amendinent, ${ }^{82}$ which would have given governors final veto power over grants by OEO to legal services units. ${ }^{83}$ Under present law such opposition can be expressed by hostile scrutiny of refunding applications for local programs that have instituted suits against the state on behalf of their chents. ${ }^{84}$ It can also be detected in a series of reorgamization plans recently considered by OEO to "regionalize" or "decentralize" legal services administration. The first of these plans ${ }^{85}$ was dropped last fall and the second ${ }^{86}$ last

82. Senator Murphy had expressed concern that "legal service organizations have diverted their major thrust from legal aid and assistance to the needy and turned that thrust toward political activism through the filing of law suits against governmental agencies." S. REP. No. 91-453, 91st Cong., 1st Sess. 63 (1969). On October 14, 1969, he imtroduced his amendment to the Economic Opportunity Amendments of 1969, Pub. L. No. 91-177, 83 Stat. 827, amending 42 U.S.C. \$\$ 2701 et seq. (1964; Supp. V, 1970), on the floor of the Senate. 115 CoNG. REc. 29894 (1969).

83. Robb, supra note 79, at 329.

84. See note 79 supra.

85. The "Regionalization Plan," set forth in a memorandum dated August 12, 1970, from Wesley L. Hjorneuik, Deputy Director of OEO, to the Legal Services Director, was opposed by poverty groups, public service groups, the American Bar Association, and others. Hearings on Legal Services Program of the Office of Economic Opportunity Before the Subcomm. on Employment, Manpower, and Poverty of the Senate Comm. on Labor and Public Welfare, 91st Cong., 2d Sess. pt. 2, at 140-69, 186-236, 239-330, 564-65, passim (1970). On November 12, 1970, OEO announced that this plan would not be implemented, largely because of opposition from the organized bar. N.Y. Times, Nov. 13, 1970, at 19, col. 1. See also Memorandum from OEO Director to Semior Staff and Regional Directors re Administration of the Legal Services Program, Nov. 14, 1970.

86. The "Decentralization Plan," a modified version of the regionalization proposal, was set forth im a memorandum dated November 14, 1970, froin Donald Rums- 
winter because of strong opposition from the bar and other groups. Each would have conferred much of the authority now vested in the Director of the Office of Legal Services and his staff upon the ten regional directors of OEO. Since regional directors are recruited primarily to administer the highly politicized OEO community action programs, they are attuned to the need to mediate among conflicting political forces at the state and local level. ${ }^{87}$ They tend to be highly sensitive and responsive to the demands of politically dominant elements within state and local government and seek trade-offs between the interests perceived by state and local officials and the goals of poverty community constituencies.

Arguably, such an orientation is useful in administration of community action programs. Direct involvement of the poor in municipal pohitical and administrative structures may not be feasible without the kind of political brokerage that can be provided by a regional director; one who has strong relationships with state and local officials and who is ready to give as well as take in working out viable arrangements may be essential if the poor are to gain a greater voice in planning and adininistering the political programs affecting them. A similar analysis could, of course, be pressed in support of giving regional directors power over legal services. Hypothetically, net gains might be achieved for the poor by trade-offs at the local level; aggressive legal services functions could be bartered away, for exainple, in return for cominunity representation in a model cities agency. Treating legal services as but one element in a set of local engagements on behalf of the poor would thus make for greater comprehensiveness in the planning of a local strategy which took into account attendant pohtical constraints.

But given the professional characteristics of a lawyer's work, and given the kinds of legal problems that in fact confront the poor, it would be devastating to the quality of legal services to link it directly to community action programs and related political controls. For the poor, legal problems are largely entanglements with the state and local bureaucracy. It is the state highway department, the mass transit district, or the inunicipal redevelopment agency that may fashion a program responsive to other interests and which may demean the environment of the poor or reduce the stock of low cost housing. It is an agency of the state that may administer a welfare prograun in ways denying dignity or sustenance or both to some members of the intended beneficiary group. It is a local housing authority that may administer its units

feld, OEO Director, to the Legal Services Director. Mr. Rumsfeld announced on December 12,1970, that this plan, too, was being withdrawn because of widespread opposition. N.Y. Times, Dec. 15, 1970, at 23, col. 3.

87. See Arnold, supra note 79, at 5-8. 
in ways no clientele would tolerate in a private market setting. A legal service director at the national level, if steeped in the lawyer's tradition and strongly committed to a forceful legal service program, may be able to withstand even strong pressure from state and local officials to throttle back on vigorous lawyering. It is mucli less likely that a regional director, closer to the source of the pressure and lacking the defenses of a professional tradition, would be able to do so.

The most troublesome aspect of the recent reorganization flurry is the implication for the future. The Murphy Amendment was not a part of the administration's program, but was offered as a floor amendment..$^{88}$ By contrast, the comparably crippling reorganization proposals were initiated within the administration. If the concept of independent legal service does not lave the ardent support of those responsible for the program, its prospects for survival are dim indeed. Administrative reorganization is not the only way in which the program could be weakened by those who run it. ${ }^{89}$

Independence to act in his client's interest as he sees it is essential to the lawyer if he is to function as a lawyer at all. The legal services concept is founded, ultimately, upon the conviction that the American society, through established processes, may afford redress for inany of the grievances of the poor. The intuition is that skilled professionals by invoking those processes may achieve substantive gains for the poor, rectify resource allocations which are not consistent with governing norms embodied in national policy, and decelerate the downward spiral of violence followed by repression followed by nore violence by providing orderly and effective means for redressing deeply felt wrongs. A legal services program responsive to this model could not survive an oinnipresent and threatening system of political checks exercised by state and local governinent upon the deployment of legal service resources. No lawyer can serve his chients well, or even honestly, if his activities are subject in significant degree to the control of his chent's adversaries.

Recently, the American Bar Association, through its president, expressed opposition to the regionalization plan and urged OEO to "reaffirm the independent status of the Legal Services Program at all levels of administration . . . ." Tho This position is eminently sound. If legal

88. See note 82 supra.

89. It has been reported that the administration currently has under consideration a plan to "reprivitize" the legal services program by taking it out of OEO and making it the responsibility of an independent federal corporation. Arnold, supra note 79, at 4. The details of any new reorganization plan should be critically evaluated to assure that legal services lawyers remain professionally imdependent and are effectively insulated from political pressures.

90. Letter from Edward L. Wright, President of the American Bar Association, to Donald Rumsfeld, OEO Director, Oct. 16, 1970. 
services are to affect the quality of life of the poor, then the quality of the legal services program unust not only be maintained but improved. The need is for more broadly gauged lawyering, involving the use of coinprehensive impact strategies which may achieve gains for substantial segments of the poor, not for a tame and tepid program carried out by lawyers who fear reprisal if they challenge state or local government. ${ }^{01}$ But a quality program cannot be achieved if the independence of the legal services lawyer is sacrificed.

\section{CONCLUSION}

Professional independence is not a privilege which can be parcelled out in portions of different sizes. Its availability to all lawyers representing all interests is a precondition to the validity of any decision-making system in which advocacy plays a part. The vital social interest in protecting the professional independence of legal services lawyers has a unique call upon the interests of members of the bar. Lawyers ask of the society as a whole a unique indulgence. In the role of advocate, the lawyer seeks with force, vigor, and imagimation to turn social decision making processes to the narrowly partisan, private interests of the chent he represents. For this contribution, he expects not the disdain of the society but its respect; his professional ideology insists that by serving private interests well, he serves the cominon interest also, for his skills serve to refine the products introduced into the marketplace of ideas in which public decisions are made. But the lawyer's vision of his function can accord witl reality only if skilled, independent, and ardent advocacy can be harnessed in support of all competing conceptions from among which social choices are made. The organized bar and lawyers generally should therefore press as forcefully as they can their continued opposition to any step tending to reduce that independence and should concern theinselves directly with the commitment and quality of legal services leadership and administration.

91. Lawyering of this kind is, of course, not the sole preserve of OEO funded poverty lawyers. When talented, experienced lawyers drawn from large-firm corporate or government practice become involved in developing legal strategies for the poor, the result, typically, is an impact strategy aimed at significant changes in the institutional environment of the client. See, e.g., 2 SAN FrAncisco LAWYeR's COMM. FOR URBAN AFFAIRS ANN. REP. (1970), which indicates that during 1970 this volunteer organization, utilizimg the services of just such lawyers, engaged in the following: Assisted in establishing 20 community-owned businesses, including a housing development corporation, and a feeder busline; assisted in developing 25 nonprofit projects, including a half-way house for Indian ex-convicts, a Black-area neighborhood college, and four drug treatment clinics; initiated class actions aimed at improving conditions in the county jails, setting aside restrictions on the use of methadone to treat drug addiction, and reducing racial discrimination in housing rentals. 


\section{California Law Review}

\begin{tabular}{lll}
\hline \hline VoL. 59 & JANUARY 1971 & No. 1 \\
\hline \hline
\end{tabular}

\section{BOARD OF EDITORS}

Editor-in-Clief

JOSEPH T. KIEFER

Chief Managing Editor

ROBERT D. EvaNS
Supreme Court Editor

GREGORY J. HoBBS, JR.
Notes \& Comments

KENT SINCLAIR, JR.

D. REBECCA SNOW

Peter J. Aschenkrenner

JAMES R. FARRAND

PAUTL E. GIIBERT

Paul W. GlenN

Michael L. MEyers

Bruce S. RosS

KENT A. Russell

JaMES TOLEDANO

MerRick JoHN BobB

William M. Chamberlatn

Diane D. Eames

ROBERT ERICSON

GENE HARTER

DAVID M. ACHTERKIRCHEN

ROBERT C. BARRETT

Steven A. Brick

LAWRENCE R. BROWN

MARY Jo Christensen

JOHN F. DaVIS

Steven M. DRUKer

HENRY C. EAMES, JR.

AUBAN ANN EISENHARDT

Chardes R. Farrar, JR.
Articles

WILLIAM F. CoOK

Steven Finell

Douglas Alan Oglesby

Maria TANKenson

Book Reviews

J. Michael BrennaN

Mary DunLaP

Executive Editor

WiLliam BillingsLea, Jr.

Associate Editors

Ellyn A. Hershman

JUDITH G. KLEINBERG

RoBIN MEADOW

LAWRENCE B. ORDOWER

Richard L. PEREz

JAMES C. FOWLER

HAROLd FRIEdMan

CAROL, G. HAMMETT

DAVID I. HAMMETT

JIMMIE HARRIS

ROBERT I. HARRIS

SPENCER R. KAITZ

DenNis S. KarJala

Sheila S. Kato

RrCHARD MARCUS

Thomas M. MUrRaY

Administrative Aide

Susan G. Vega
Research

G. KIP EDWARDS

DAVID R. ANDREWS

Chardes H. Hurd

Douglas M. Laurice

ROBERT LEVY

Managing

DaRVISH M. KoRDESTANI

Michael George KozaK

JoHN E. MASON, JR.

RICHARD L. PARRISH

Omar Petrona

Peter E. Sheenan

Margaret SHerWOOD

Michael B. SMMON

ROBERT D. STRATMORE

Carol Bruch Myers

ElaINe T. NELSON

LYNN H. PASAHOW

ReX Perschbacher

THOMAS B. ROSENBERG

ROBERT K. SCHIEBELHUT

MARK Harold SHENFiELd

Susan J. Tamura

SCOTT R. WILLERT

STEPHEN ZAMORA 